\title{
Meningkatkan Prestasi Belajar IPS Melalui Penerapan Model Pembelajaran Problem Posing Siswa
}

\author{
I Gusti Putu Taram ${ }^{1}$ \\ 1SMP Negeri 2 Blahbatuh, \\ Gianyar, Indonesia \\ email: gustitaram62@gmail.com
}

\begin{abstract}
Abstrak
Penelitian ini dilaksanakan di SMP kelas VII A yang kemampuan siswanya untuk mata pelajaran IPS masih sangat rendah. Tujuan penulisan penelitian tindakan kelas ini adalah untuk meningkatkan prestasi belajar IPS siswa kelas VII pada semester I tahun pelajaran 2019/2020 melalui penerapan model pembelajaran Problem Posing. Metode pengumpulan datanya adalah tes prestasi belajar. Metode analisis datanya adalah deskriptif baik untuk data kualitatif maupun untuk data kuantitatif. Hasil yang diperoleh dari penelitian ini adalah penerapan model pembelajaran Problem Posing dapat meningkatkan prestasi belajar siswa. Ini terbukti dari hasil yang diperoleh pada awalnya mencapai nilai rata-rata 68,02 , pada siklus I mencapai nilai rata-rata 74,86 dan pada siklus II mencapai nilai rata-rata 81,97. Presentase ketuntasan belajar siswa juga mngalami peningkatan. Pada awal pembelajaran ketuntasan belajar siswa hanya mencapai $31,57 \%$. Pada siklus I mengalami peningkatan menjadi $73,68 \%$, dan pada siklus II ketuntasan belajar siswa meningkat menjadi $100 \%$. Kesimpulan yang diperoleh dari penelitian ini adalah prestasi belajar IPS siswa kelas VII tahun pelajaran 2019/2020 dapat ditingkatkan melalui penerapan model pembelajaran Problem Posing.
\end{abstract}

Kata Kunci: Prestasi Belajar, Model Pembelajaran Problem Posing, Metode Bimbingan Individu dan Kelompok.

\begin{abstract}
This research was conducted at SMP in class VII A, where the students' ability for social studies subjects was still very low. The purpose of this classroom action learning is to improve the social studies achievement of class VII A students of SMP in the first semester of the 2019/2020 academic year through the application of the Problem Posing learning model. The data learning method is a learning achievement test. The data analysis method is descriptive both for qualitative data and for quantitative data. The results obtained from this study are the application of the Problem Posing learning model can improve student achievement. This is from the results obtained at first reaching an average value of 68.02 , in my cycle it was proven to reach an average value of 74.86 and in the second cycle it reached an average value of 81.97 . The percentage of student learning completeness has also increased. At the beginning of the learning completeness of students only reached $31.57 \%$. In the first cycle the increase was $73.68 \%$, and in the second cycle student learning completeness increased to $100 \%$. The conclusion obtained from this study is that the social studies achievement of class VII students in the 2019/2020 school year can be improved through the application of the Problem Posing learning model.
\end{abstract}

Keywords: Learning Achievement, Problem Posing Learning Model, Individual and Group Guidance Methods.

\section{Pendahuluan}

Tujuan dari suatu proses pembelajaran adalah untuk membentuk anak didik dalam suatu perkembangan tertentu. Dalam suatu proses belajar mengajar, aspek yang sangat penting untuk mencapai tujuan tersebut adalah peran aktif atau partisipasi antara guru dan

\footnotetext{
${ }^{*}$ Corresponding author
}

Received 03 Februari 2020; Accepted 31 July 2020; Available online 1 September 2020 (C) 2020 MPI. All Rights Reserved 
siswa. Partisipasi antara keduanya sangat berpengaruh terhadap pencapaian tujuan pembelajaran yang diinginkan. Hal ini dapat diartikan bahwa dalam suatu proses belajar mengajar harus ada keterlibatan antara guru dan siswa. Proses belajar itu sendiri merupakan hal yang sangat penting, dimana proses tersebut terjadi di dalam pemikiran siswa. Keterlibatan siswa dalam proses belajar mengajar merupakan suatu implementasi dari keaktifan siswa dalam proses tersebut tentu saja disamping menerima materi pelajaran dari guru siswa juga aktif baik dari segi fisik maupun mental.

Demi tercapainya tujuan tersebut, maka guru memegang peranan penting. Oleh sebab itu guru di sekolah tidak hanya sekedar mentransferkan sejumlah ilmu pengetahuan kepada murid-muridnya, tetapi lebih dari itu terutama dalam membina sikap dan ketrampilan mereka (Bambang, 2019). Untuk membina sikap murid di sekolah, dari sekian banyak guru bidang studi, guru bidang studi agamalah yang sangat menentukan, sebab pendidikan agama sangat menentukan dalam hal pembinaan sikap siswa karena bidang studi agama banyak membahas tentang pembinaan sikap, yaitu mengenai aqidah dan akhlakul karimah.

Guru sebagai figur sentral dalam dunia pendidikan, khususnya dalam proses belajar mengajar. Sehubungan dengan ini, setiap guru sangat diharapkan memiliki karakteristik (ciri khas) kepribadian yang ideal sesuai dengan persyaratan yang bersifat psikologis-pedagogis.

Peran ganda seorang guru yaitu sebagai pengajar sekaligus sebagai pendidik. Dalam rangka mengembangkan tugas atau peran gandanya maka guru memiliki persyaratan kepribadian sebagai guru yaitu: Suka bekerja keras, demokratis, penyayang, menghargai kepribadian peserta didik, sabar, memiliki pengetahuan, ketrampilan dan pengalaman yang bermacam-macam, perawakan menyenangkan dan berkelakuan baik, adil dan tidak memihak, toleransi, mantap dan stabil, ada perhatian terhadap persoalan peserta didik, lincah, mampu memuji, perbuatan baik dan menghargai peserta didik, cukup dalam pengajaran, mampu memimpin secara baik.

Demi tercapainya tujuan tersebut, maka guru memegang peranan penting. Oleh sebab itu guru di sekolah tidak hanya sekedar mentransferkan sejumlah ilmu pengetahuan kepada murid-muridnya, tetapi lebih dari itu terutama dalam membina sikap dan ketrampilan mereka. Untuk membina sikap murid di sekolah, dari sekian banyak guru bidang studi, guru bidang studi agamalah yang sangat menentukan, sebab pendidikan agama sangat menentukan dalam hal pembinaan sikap siswa karena bidang studi agama banyak membahas tentang pembinaan sikap, yaitu mengenai aqidah dan akhlakul karimah.

Tugas guru tidak terbatas pada memberikan informasi kepada murid namun tugas guru lebih konprehensif dari itu. Selain mengajar dan membekali murid dengan pengetahuan, guru juga harus menyiapkan mereka agar mandiri dan memberdayakan bakat murid di berbagai bidang, mendisiplinkan moral mereka, membimbing hasrat dan menanamkan kebajikan dalam jiwa mereka. Guru harus menunjukkan semangat persaudaraan kepada murid serta membimbing mereka pada jalan kebenaran agar mereka tidak melakukan perbuatan yang menyimpang dari ajaran agama.

Apabila seorang guru memahami hal-hal tersebut tentu saja prestasi belajar siswa tidak akan rendah. Namun kenyataan yang ada di lapangan sangat jauh berbeda. Berdasarkan hasil observasi peneliti selaku guru di SMP Negeri 2 Blahbatuh rata-rata prestasi belajar siswa hanya mencapai 68,02 dengan ketuntasan belajar hanya $31,57 \%$. Hal tersebut masih jauh di bawah KKM mata pelajaran IPS di sekolah ini yaitu 73,00.

Ada beberapa kemungkinan faktor penyebab rendahnya prestasi belajar siswa pada mata pelajaran IPS, diantaranya faktor siswa, guru, sarana prasarana, alat peraga, metode, dan proses mengajar yang kurang menarik minat siswa untuk belajar. Siswa kurang memperhatikan guru saat menerima pelajaran, kurang fokus, enggan berpikir, merasa malu dan bosan. Guru kurang persiapan dalam merencanakan pembelajaran dan kurang menguasai materi pembelajaran. Dalam proses belajar mengajar masih satu arah dan masih beranggapan guru itu segalanya. Berdasarkan beberapa kemungkinan penyebab tersebut peneliti berusaha mencari penyebab yang muncul di kelas mengenai minat siswa dalam pembelajaran IPS masih rendah karena pengajaran materi kurang menarik, sarana pendukung (alat peraga) untuk pembelajaran masih rendah dan kompetensi guru dalam merencanakan. 
Menghadapi kondisi yang sangat mengkhawatirkan, maka perlu adanya upaya perbaikan dalam proses pembelajaran agar dapat meningkatkan keterampilan proses dalam pembelajaran IPS yaitu khususnya pada kemampuan analisis dalam memahami materi IPS Salah satu alternatif yang digunakan yaitu dengan menggunakan model pembelajaran Problem Posing. Model pembelajaran Problem Posing merupakan suatu pendekatan dalam pembelajaran yang membantu siswa untuk menemukan masalah dari suatu peristiwa yang nyata, mengumpulkan informasi melalui strategi yang telah ditentukan sendiri untuk mengambil satu keputusan pemecahan masalahnya yang kemudian akan dipresentasikan dalam bentuk unjuk kerja.

Dengan penerapan model pembelajaran Problem Posing diharapkan kemampuan analisis siswa dapat meningkat. Pembelajaran berbasis masalah tidak bisa terlepas dari metode pemecahan masalah, hal ini karena pembelajaran masalah berakar dari metode pemecahan masalah. Metode Problem Posing merupakan salah satu cara penyajian bahan pelajaran yang menjadikan masalah sebagai titik tolak pembahasan untuk dianalisis dan disintesis untuk menemukan jawaban.

\section{Metode Penelitian}

Penelitian Tindakan Kelas ini dilaksanakan di SMP Negeri 2 Blahbatuh. Penelitian ini dilakukan pada siswa kelas VII A dengan jumlah siswa 38 orang. Lingkungan sekolah ini sangat nyaman karena hubungan dengan masyarakat sekitar sekolah sangat baik, tidak bising, hubungan antara sekolah dengan masyarakat sekitar juga sangat harmonis, sehingga menimbulkan rasa mutualisme antara sekolah dan masyarakat sekitar.

Sekolah ini berada di daerah yang udaranya masih sangat bersih, pepohonan yang tumbuh juga masih sangat banyak dan rimbun, hal ini tentunya membuat siswa semakin nyaman dalam mengikuti pelajaran yang diberikan.

Penelitian ini merupakan penelitin tindakan kelas yang akan dilaksanakan dalam dua siklus. Jika pada siklus pertama prestasi belajar IPS siswa belum memenuhi kriteria keberhasilan, maka berdasarkan hasil refleksi akan dilakukan perbaikan pada siklus seanjutnya. Secara operasional prosedur dasar pengembangan tindakan yang akan dilakukan dapat dijabarkan sebagai berikut:

Untuk penelitian ini penulis memilih rancangan penelitian tindakan yang disampaikan oleh Ebbut seperti terlihat pada gambar berikut: 


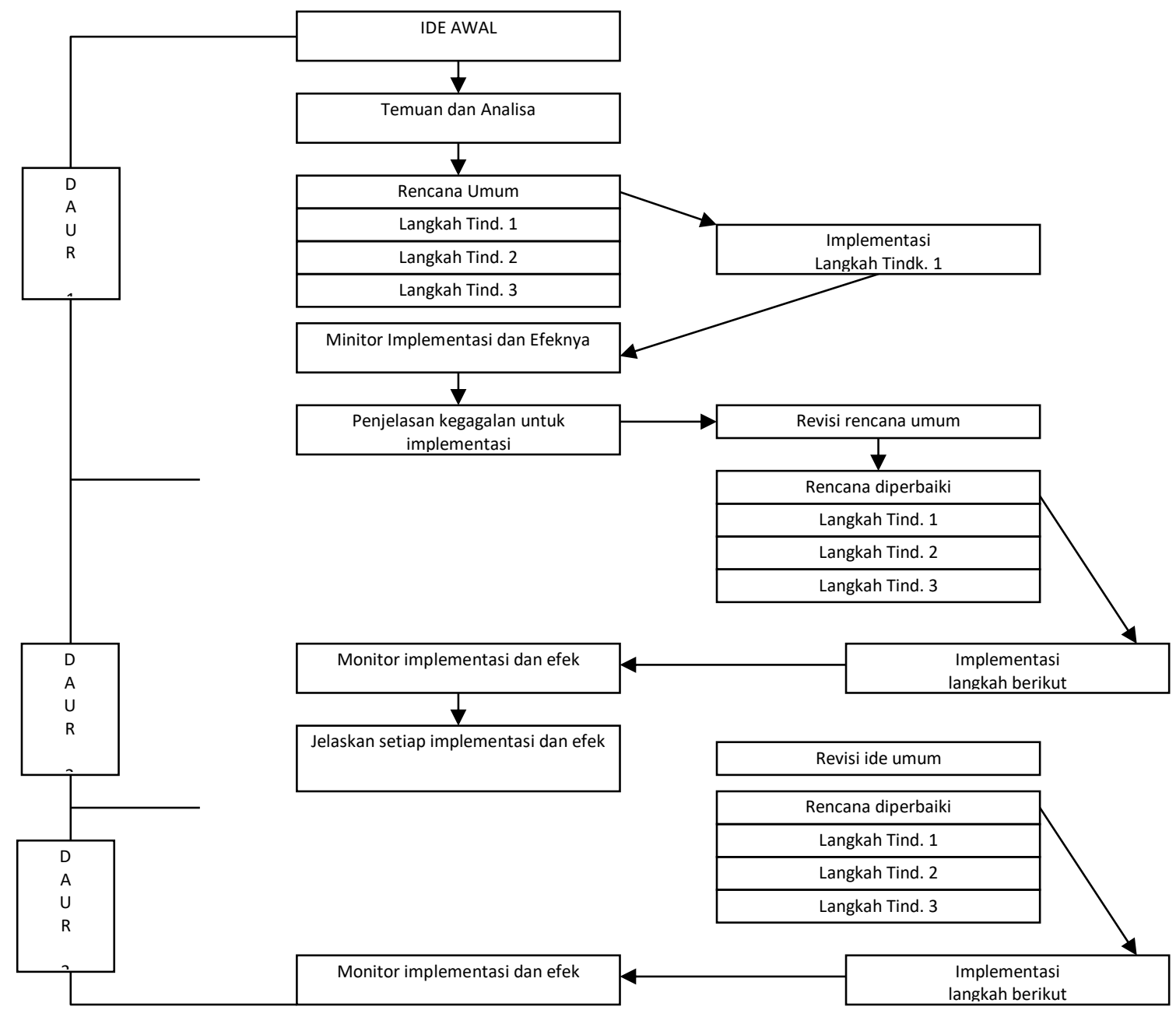

Gambar 01. Rancangan Penelitian Tindakan Model Ebbut (1985)

\section{Prosedur:}

\section{Sebagai alur PTK, Ebbut memberi contoh sebagai berikut.}

Pada daur I dimulai dengan adanya ide awal akibat temuan dan analisis yang telah dilakukan. Setelah ada temuan tersebut dibuatlah perencanaan umum sesuai langkah yang direncanakan baik tindakan 1, tindakan 2 maupun tindakan 3 . Sesudah membuat perencanaan, diimplementasikan dalam tingkat 1, dimonitoring implementasinya serta efeknya kemudian dijelaskan kegagalan-kegagalan yang ada selama implementasinya lalu dibuat revisi umum untuk perencanaan tindakan selanjutnya.

Pada tindakan selanjutnya, perencanaan yang telah dibuat diimplementasikan, terus dimonitor implementasinya serta efek yang ada, dijelaskan setiap langkah implementasinya dan efeknya.

Setelah mengetahui bagaimana hasil dan efeknya, dibuat lagi perencanaan untuk tindakan selanjutnya. Demikian berlanjut sampai menemukan hasil yang sesuai tujuan yang direncanakan.

Metode yang digunakan untuk menganalisis data hasil penelitian ini adalah metode deskriptif kuantitatif. Adapun indikator keberhasilan penelitian yang diusulkan dalam penelitian ini pada siklus I dan siklus II mencapai nilai rata-rata 74,00 dengan ketuntasan belajar minimal $85 \%$. 


\section{Hasil Dan Pembahasan}

Berdasarkan penelitian yang telah dilakukan dengan menggunakan model pembelajaran Problem Posing didapatkan hasil bahwa: pada siklus I sudah diupayakan untuk perbaikan pembelajaran untuk meningkatkan prestasi belajar IPS dengan menggunakan model Problem Posing. Peneliti telah giat melakukan kegiatan yang susuai dengan kebenaran teori yang ada sehingga peneliti memperoleh hasil yang lebih baik dari proses awal, yaitu dengan rata rata nilai 74,86 dari jumlah nilai 2845 seluruh siswa di kelas VII A SMP Negeri 2 Blahbatuh, dan prosentase ketuntasan belajarnya adalah $73,68 \%$, yang tidak tuntas adalah $26,31 \%$. Hasil ini belum maksimal, karena belum mecapai indikator keberhasilan penelitian yang mencanangkan dengan minimal prosentase ketuntasan belajar $85 \%$.

Pelaksanaan penelitian pada siklus II terlihat proses pembelajaran sudah semakin baik. Siswa terlihat sangat aktif dalam proses pembelajaran. Hal ini berdampak positif terhadap peningkatan prestasi belajar IPS siswa. Rata-rata prestasi belajar IPS siswa pada siklus II adalah 81,97, dan ketuntasan belajarnya adalah $100 \%$. Hasil ini mengindikasikan bahwa prestasi belajar IPS siswa kelas VII A semester I SMP Negeri 2 Blahbatuh tahun pelajaran 2019/2020 dapat ditingkatkan melalui penerapan model pembelajaran Problem Posing.

Model pembelajaran problem posing adalah suatu model pembelajaran yang mewajibkan para siswa untuk mengajukan soal sendiri melalui belajar membuat soal secara mandiri (Astra, 2012). Pembelajaran denganproblem posing adalah suatu pembelajaran dengan cara siswa diminta untuk merumuskan, membentuk dan mengajukan pertanyaan atau soal dari situasi yang disediakan, situasi dapat berupa gambar, cerita, atau informasi lain yang berkaitan dengan materi pelajaran, dan selanjutnya siswa sendiri yang harus mendesain cara penyelesaiannya (Nurlaila et all., 2013). Fungsi guru dalam kegiatan itu adalah memotivasi siswa agar aktif mengikuti kegiatan pembelajaran dan membimbing siswa dalam proses pemecahan atau penyelesaiannya.

Hasil penelitian ini sejalan dengan hasil penelitian yang dilakukan oleh (Hatmawati, et sl., 2016) dengan judul Penerapan Model Pembelajaran Problem Posing dengan Metode Eksperimen untuk Meningkatkan Hasil Belajar Fisika pada Siswa Kelas VIII SMPNegeri 19 MataramTahun Pelajaran 2015/2016. Berdasarkan hasil penelitian dan pembahasan dapat disimpulkan bahwa penerapan model pembelajaran problem posingdengan metode eksperimen dapat meningkatkan hasil belajar fisika pada siswadi kelas VIII-C SMP Negeri 19 Mataram tahun pelajaran 2015/2016 pada materipokok tekanan.

Selanjutnya penelitian yang dilakukan oleh (Erianti et al.,2017) dengan judul Pengaruh Model Pembelajaran Problem Posing Dipadu Media Audio Visual Terhadap Keterampilan Berpikir Kritis dan Hasil Belajar Siswa Pada Materi Sistem Endokrin di Mas Babun Najah Banda Aceh. Dalam penelitiannya disimpulkan bahwa model pembelajaran Problem Posing dipadu media audio visual berpengaruh terhadap keterampilan berpikir kritis dan hasil belajar siswa.

\section{Simpulan}

Dari penelitian yang telah dilakukan ditemukan data awal ada 26 siswa mendapat nilai dibawah KKM dan pada siklus I menurun menjadi 10 siswa dan siklus II tidak ada siswa mendapat nilai di bawah KKM, Nilai rata-rata awal 68,02 naik menjadi 74,86 pada siklus I dan pada siklus II naik menjadi 81,97. Dari data awal siswa yang tuntas hanya 12 orang sedangkan pada siklus I menjadi lebih banyak yaitu 28 siswa dan pada siklus II sebanyak 38 siswa sudah memenuhi KKM. Berdasarkan temuan di atas, dapat disimpulkan bahwa prestasi belajar IPS siswa kelas VII A semester I SMP Negeri 2 Blahbatuh tahun pelajaran 2019/2020 dapat ditingkatkan melalui penerapan model pembelajaran Problem Posing. 


\section{Daftar Pustaka}

Amri, Sofan. 2013. Peningkatan Mutu Pendidikan Sekolah Dasar dan Menengah. Jakarta: PT. Prestasi Pustakaraya.

Arikunto, Suharsimi; Suhardjono; Supardi. 2006. Penelitian Tindakan Kelas. Jakarta: PT Bumi Aksara.

Astra, I. M., Umiatin, dan Jannah, M. 2012. Pengaruh Pembelajaran Problem PosingTipe PreSolution PosingTerhadap Hasil Belajar fisika dan Karakter Siswa SMA. Jurnal pendidikan Fisika Indonesia, 8: 135-143.

Badan Standar Nasional Pendidikan. 2007. Peraturan Menteri Pendidikan Nasional Republik Indonesia Nomor 41 Tahun 2007. Jakarta: BSNP.

Bambang Erawan, I. (2019). Upaya Meningkatkan Prestasi Belajar Pkn Melalui Penerapan Model Pembelajaran Index Card Match Pada Siswa Kelas Vi Sd Negeri 5 Gianyar Semester li Tahun Pelajaran 2018/2019. Widyadari, 21(26), 1-12.

Dahar, Ratna Wilis. 1989. Teori-Teori Belajar. Jakarta: Penerbit Erlangga.

Daryanto. 1999. Evaluasi Pendidikan. Rineka Cipta: Jakarta.

Depdiknas, 2003c. Sistem Penilaian Kelas SD, SMP, SMA dan SMK. Dirjen Dikdasmen Tendik.

Depdiknas. 2002. Problem Posing. Jakarta: Dirjen Pendidikan Dasar dan Menengah.

Depdiknas. 2008. Pengolahan dan Analisis Data Penelitian. Jakarta: Direktorat Tenaga Kependidikan Dirjen PMPTK.

Depdiknas. 2011. Membimbing Guru dalam Penelitian Tindakan Kelas. Jakarta: Pusat Pengembangan Tenaga Kependidikan Badan Pengembangan Sumber Daya Manusia Pendidikan dan Menjaminan Mutu Pendidikan.

Dimyati dan Mudjiono. 2001. Belajar dan Pembelajaran. Jakarta: Dirjen Dikti.

Djamarah, Syaful Bahri. 2002. Prestasi belajar dan Kompetensi Guru. Surabaya: Usaha Nasional.

Erianti, Dewi, dkk. 2017. Pengaruh Model Pembelajaran Problem Posing Dipadu Media Audio Visual Terhadap Keterampilan Berpikir Kritis dan Hasil Belajar Siswa Pada Materi Sistem Endokrin di Mas Babun Najah Banda Aceh. Jurnal EduBio Tropika, Volume 5, Nomor 1, April 2017.

Hartinah DS, Haji Sitti. 2009. Konsep Dasar Bimbingan Kelompok. Bandung: PT. Refika Aditama.

Hatmawati, Sofiana Rahmiatu, dkk. 2016. Penerapan Model Pembelajaran Problem Posing dengan Metode Eksperimen untuk Meningkatkan Hasil Belajar Fisika pada Siswa Kelas VIII SMPNegeri 19 MataramTahun Pelajaran 2015/2016. Jurnal Pendidikan Fisika dan Teknologi (ISSN. 2407-6902) Volume II No 1, Januari 2016.

Nurlaila, N, Suparmi, Sunarno, W. 2013. Pembelajaran Fisika dengan PBL Menggunakan Problem Solving Dan Problem Posing Ditinjau dari Kreativitas danKeterampilan Berpikir Kritis Siswa. Jurnal Inkuiri ISSN2 (2): 114-123. 